\title{
Influence of Bearing Stratum on the Deformation of Geosynthetic Reinforced and Piled Embankments
}

\author{
Di WU \\ College of Architecture and Transportation Engineering \\ Guilin University of Electronic Technology \\ Guilin, China \\ E-mail: adi823@163.com
}

\author{
Zhuangzhuang PU \\ College of Architecture and Transportation Engineering \\ Guilin University of Electronic Technology \\ Guilin, China \\ E-mail: 13978335972@163.com
}

\author{
Dan LI \\ College of Architecture and Transportation Engineering \\ Guilin University of Electronic Technology \\ Guilin, China \\ E-mail: 764937566@qq.com
}

\begin{abstract}
Geosynthetic reinforced and piled embankments are new type of embankments construction on soft soil foundation in recent years. Until now, the researches on this embankment structure have been carried out from theoretical analysis, numerical analysis, model tests, field tests, et al. However, in practical engineering applications, sometimes it is difficult to find a better bearing stratum. So it is necessary to study the influence of pile bearing stratum. In this paper, the influence of bearing stratum on the vertical and lateral displacement of geosynthetic reinforced and piled embankments was studied by using numerical analysis as the main method and comparing with the results of field tests, which could provide references of practical engineering applications. The results showed that the foundation of the embankments were stable as well as the deformation was small when the bearing stratum was the bedrock; there was a certain degree of penetration when the bearing stratum was sand layer; local shear failure occurred at the end of the pile when the bearing stratum was soft soil layer.
\end{abstract}

Keywords-geosynthetic reinforced and piled embankments; bearing stratum; numerical analysis; settlement; lateral displacement

\section{INTRODUCTION}

With the rapid development of railway and highway constructed in China, available lands have become limited, and many projects have to be constructed on the sites which were not considered suitable for construction in the past, higher requirements are proposed for the application of foundation treatment technology and the control of foundation deformation. Therefore, it is necessary to adopt some way to deal with the soft soil, in order to meet the stability and deformation requirements of building foundation [1-2].

The geosynthetic reinforced and piled embankment is a new type of embankment structure, refers to piling according to a certain distance in the soft soil foundation at first, and then pouring the concrete pile cap at the top of the piles to an appropriate size, thirdly laying geosynthetic reinforced cushion on the top of the pile cap, finally filling embankments according to the design heights (as shown in Fig. 1)[3-6]. Geosynthetic reinforced and piled embankments are composed of embankment fill, horizontal reinforcement, piles and pile caps, soft soil between the piles and bearing stratum at the pile tips, which can effectively control the uneven settlement of the foundation and restrain the lateral deformation.

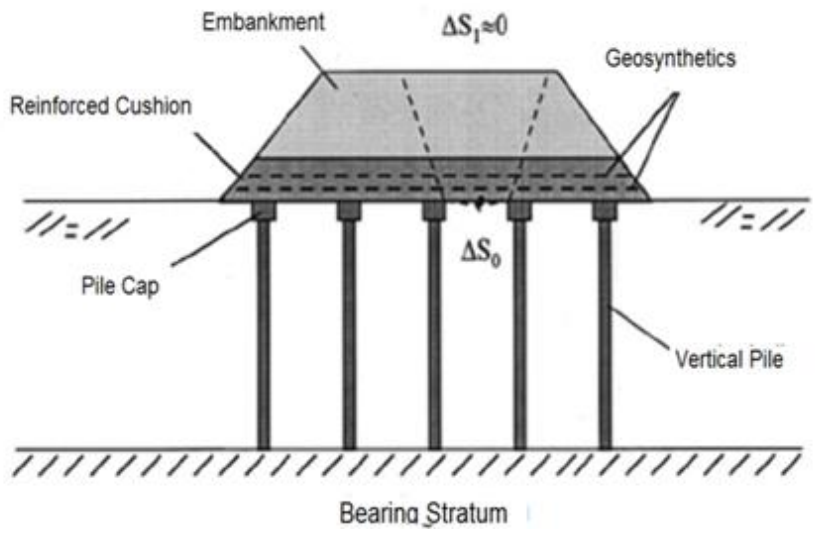

Figure 1. Geosynthetic reinforced and piled embankments.

In this paper, bearing stratum at the pile tips of geosynthetic reinforced and piled embankments was taken as the object of this study, and numerical analysis was taken as the main method. Three different types of pile tip bearing stratum were considered as M1, M2, M3, to study the influence of the deformation characteristics of reinforced and piled embankments.

\section{NUMERICAL ANALYSIS}

\section{A. Model Building}

In this paper, the field test of geosynthetic reinforced and piled embankment of Wuhan-Guangzhou Passenger Dedicated Line is selected as an engineering example project. The field tests included information of physical mechanics, 
field settlement measurements, and geosynthetic strain after construction. Numerical analysis models were built and tested based on the information.

By calculation and simulation of the numerical models, the deformation characteristics of pile-supported reinforced embankment were analyzed. The engineering geological conditions of the project are reasonably simplified, that is, the particularity of the problem was transformed into commonality, as shown in Fig. 2. The standard numerical model, as shown in Fig. 3 was established.

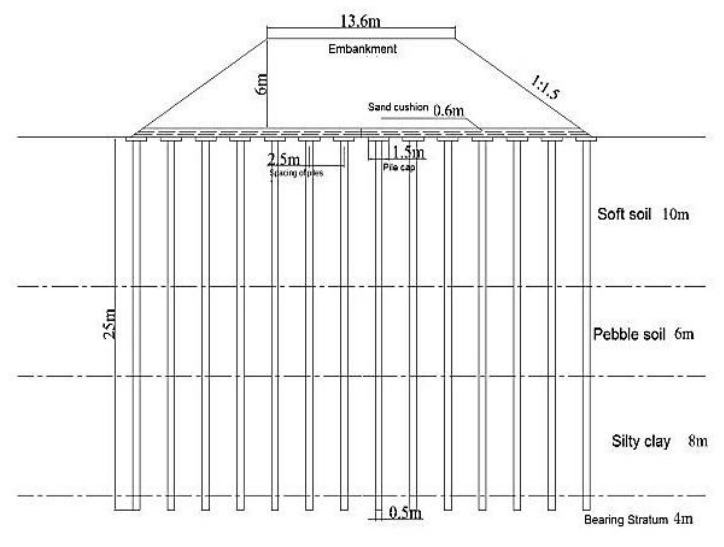

Figure 2. Cross-sectional view of the project.

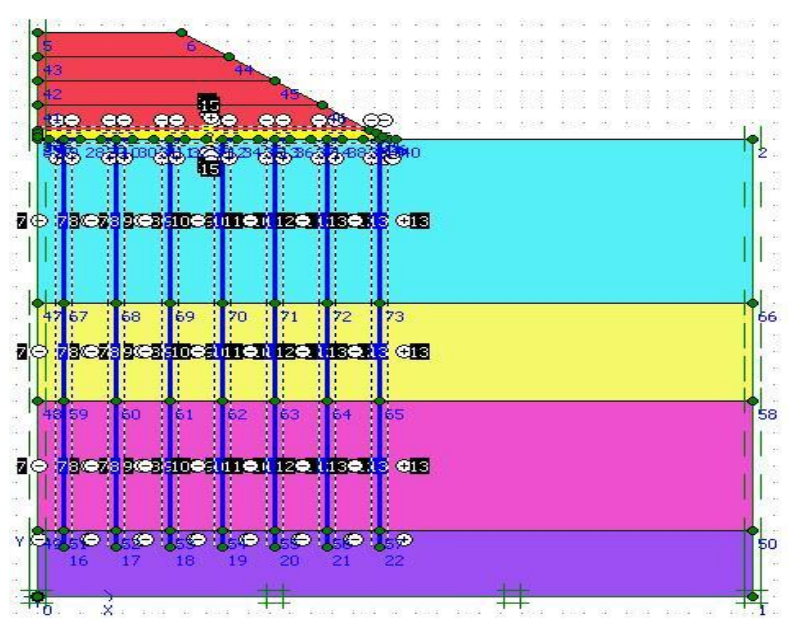

Figure 3. Geometric model diagram.

\section{B. Parameter Selection}

Determination of geosynthetics parameters referred to the strength index given by geosynthetics factory. Under normal circumstances, sand or gravel cushion could be set up on the top of the piles in order to speed up the foundation drainage. Geosynthetics was often laid in the middle of the cushion.

According to the analysis of the geological data, soil physical and mechanical parameters were determined, which used in the numerical analysis as shown in Table I and Table II. The plate element was used to simulate the piles and pile caps, and EA and El were assigned by equivalent principle. The parameters were shown in Table III. The geogrid tensile strength was determined as $1200 \mathrm{kN} / \mathrm{m}$ according to the stretching tests.

\section{Calculation Process}

The initial calculation process was the balance of the insitu stress, the application of the gravity, and the generation of the initial stress. And then, concrete piles and pile caps were constructed, cushion layer was filled, geotextile was set up, in which the thickness was $0.6 \mathrm{~m}$ as the reinforced cushion. At last, embankment was filled from $0.6 \mathrm{~m}$ to $2.2 \mathrm{~m}$, $2.2 \mathrm{~m}$ to $3.6 \mathrm{~m}, 3.6 \mathrm{~m}$ to 5.2 , and $5.2 \mathrm{~m}$ to $6.6 \mathrm{~m}$.

The model boundary condition is the standard fixed boundary in Plaxis software, which means that the boundary of the model is $u_{x}=0$ on both sides of the model, and the bottom boundary is geometric constraint $\mathrm{u}_{\mathrm{x}}=\mathrm{u}_{\mathrm{y}}=0$.

TABLE I. TABLE SOIL PARAMETERS OF EMBANKEMENTS AND FOUNDATION

\begin{tabular}{|c|c|c|c|c|c|c|}
\hline \multicolumn{2}{|c|}{ Soil } & (1) & (2) & (3) & (4) & (5) \\
\cline { 3 - 7 } & $\begin{array}{c}\text { Embank } \\
\text { ment }\end{array}$ & $\begin{array}{c}\text { Sand } \\
\text { cushio } \\
\mathrm{n}\end{array}$ & $\begin{array}{c}\text { Soft } \\
\text { Soil }\end{array}$ & $\begin{array}{c}\text { Land } \\
\text { pebb } \\
\text { le }\end{array}$ & $\begin{array}{c}\text { Silty } \\
\text { clay }\end{array}$ \\
\hline $\begin{array}{c}\text { Natural unit } \\
\text { weight }\end{array}$ & $\begin{array}{c}\mathrm{KN} / \mathrm{m} \\
3\end{array}$ & 20 & 20 & 16 & 17 & 18 \\
\hline $\begin{array}{c}\text { Saturated unit } \\
\text { weight }\end{array}$ & $\begin{array}{c}\mathrm{KN} / \mathrm{m} \\
3\end{array}$ & 21 & 21 & 17 & 18 & 19 \\
\hline $\begin{array}{c}\text { Permeability } \\
\text { coefficient }\end{array}$ & $\mathrm{m} / \mathrm{d}$ & $\begin{array}{c}1.00 \mathrm{E}- \\
05\end{array}$ & $\begin{array}{c}9.00 \mathrm{E}- \\
04\end{array}$ & $\begin{array}{c}1.00 \mathrm{E} \\
-04\end{array}$ & 1 & $\begin{array}{c}1.00 \\
\mathrm{E}-05\end{array}$ \\
\hline $\begin{array}{c}\text { Compression } \\
\text { modulus }\end{array}$ & $\mathrm{MPa}$ & 30 & 25 & 2.7 & 9 & 6 \\
\hline Poisson ratio & - & 0.3 & 0.3 & 0.35 & 0.3 & 0.2 \\
\hline Cohesion & $\mathrm{kPa}$ & 20 & 5 & 20 & 15 & 22 \\
\hline $\begin{array}{c}\text { Internal } \\
\text { friction }\end{array}$ & $\circ$ & 30 & 30 & 13 & 30 & 20 \\
\hline
\end{tabular}

TABLE II. TABLE SOIL PARAMETERS OF BEARING StRATUM

\begin{tabular}{|c|c|c|c|c|}
\hline \multirow{2}{*}{\multicolumn{2}{|c|}{ Soil }} & \multicolumn{3}{|c|}{ (6) } \\
\hline & & \multirow{2}{*}{$\begin{array}{c}\begin{array}{c}\text { Bedrock } \\
\text { (M1) }\end{array} \\
22\end{array}$} & \multirow{2}{*}{$\begin{array}{c}\text { Sand layer } \\
\text { (M2) }\end{array}$} & \multirow{2}{*}{$\begin{array}{c}\begin{array}{r}\text { Soft soil } \\
\text { layer (M3) }\end{array} \\
18\end{array}$} \\
\hline Natural unit weight & $\mathrm{KN} / \mathrm{m}^{3}$ & & & \\
\hline $\begin{array}{l}\text { Saturated unit } \\
\text { weight }\end{array}$ & $\mathrm{KN} / \mathrm{m}^{3}$ & 23 & 20 & 19 \\
\hline $\begin{array}{l}\text { Permeability } \\
\text { coefficient }\end{array}$ & $\mathrm{m} / \mathrm{d}$ & $1.00 \mathrm{E}-04$ & $4.00 \mathrm{E}-04$ & $1.00 \mathrm{E}-05$ \\
\hline $\begin{array}{c}\text { Compression } \\
\text { modulus }\end{array}$ & MPa & 70 & 35 & 6 \\
\hline Poisson ratio & - & 0.2 & 0.3 & 0.35 \\
\hline Cohesion & $\mathrm{kPa}$ & 40 & 15 & 22 \\
\hline $\begin{array}{c}\text { Internal friction } \\
\text { angle }\end{array}$ & $\circ$ & 45 & 25 & 20 \\
\hline
\end{tabular}

TABLE III.

TABle Parameters of Piles ANd Pile CAPS

\begin{tabular}{|c|c|c|c|c|c|c|}
\hline \multirow{2}{*}{ Plate } & Material & EA & EI & $\mathrm{d}$ & $\omega$ & $v$ \\
\cline { 3 - 7 } & properties & $\mathrm{kN} / \mathrm{m}$ & $\mathrm{kNm} / \mathrm{m}$ & $\mathrm{m}$ & $\mathrm{kN} / \mathrm{m} / \mathrm{m}$ & \\
\hline Pile & Elastic & $1.0 \mathrm{e} 6$ & $1.02 \mathrm{e} 4$ & 0.35 & 8.75 & 0.2 \\
\hline Pile cap & Elastic & $1.3 \mathrm{e} 6$ & $1.0 \mathrm{e} 4$ & 0.304 & 7.5 & 0.2 \\
\hline
\end{tabular}




\section{TEST RESUlts AND DISCUSSION}

According to the engineering project mentioned above, numerical analysis was carried out, and the results calculated by the established numerical model were compared with the results of the engineering monitoring data, with emphasis on vertical settlement and lateral displacement of foundation.

\section{A. Failure Mode}

According to the numerical calculation of three different bearing stratum models, it is found that M1 and M2 foundation was not damaged in whole or in part. But the simulation indicated that the local shear failure of M3 bearing stratum of pile tip occurred, and that M2 and M3 pile tip punched into the bearing stratum, as shown in Fig. 4.

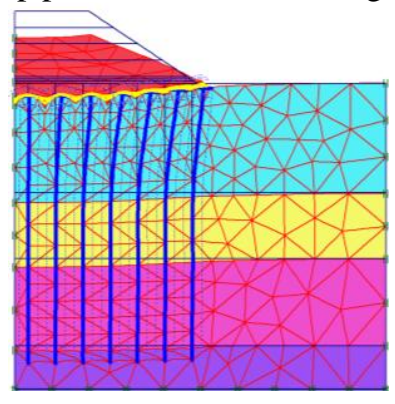

(a)

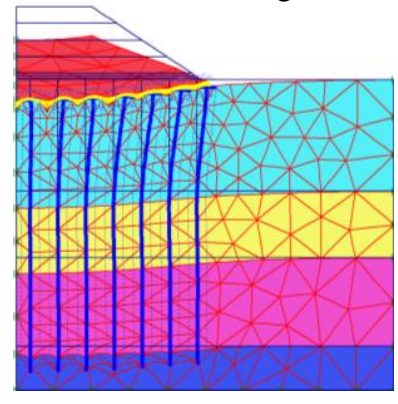

(b)

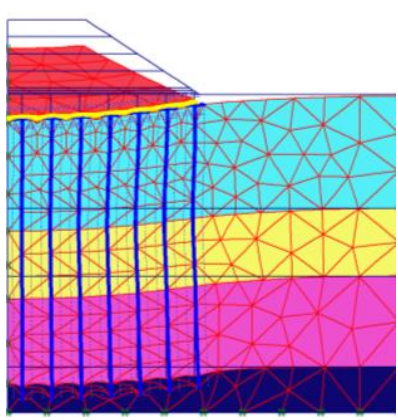

(c)

Figure 4. Comparsion of the different bearing stratum of M1(a), M2(b) and M3(c).

The results of numerical Analysis showed that the embankment was stable and the deformation was small when the bearing stratum was the bedrock layer; while when the bearing stratum was sand layer or hardpan, there were different degrees of punching, but the whole foundation was stable; when the bearing stratum was soft soil layer, local shear failure would occur near the pile tip in the bearing stratum.

\section{B. Influence of Bearing Stratum on Settlement}

Fig. 5 shows the vertical displacement of the three different bearing stratum states. The ground subsidence of the three different bearing stratum models of M1, M2 and M3 was $4.88 \mathrm{~cm}, 6.04 \mathrm{~cm}$ and $12.61 \mathrm{~cm}$, respectively.

From Fig. 6, it can be seen that with the decrease of the strength of the bearing stratum, the settlement of the pile was gradually increased. In addition, the settlement of pile caps at the center of embankment reached the maximum. The settlement of piles at the center of $\mathrm{M} 3$ reached $105 \mathrm{~mm}$, while the settlement near the foot of embankment was only $46 \mathrm{~mm}$. It can be seen that there were obvious differential in the settlement of pile caps, which correspond to the different pile tip bearing stratum.

With the embankment gradually filled, settlements of pile caps and soil gradually increased, and the former was slightly larger than the latter. Fig. 7 shows the differential settlement curves of pile-soil with three different bearing stratums. It can be seen from the figure that the differential settlement of M1, M2 was the larger, while the difference of M3 was the smallest. It can be seen that as the strength of the bearing stratum decreased, the piles punched more into the bearing stratums, and the differential settlements between piles and soil decreased.

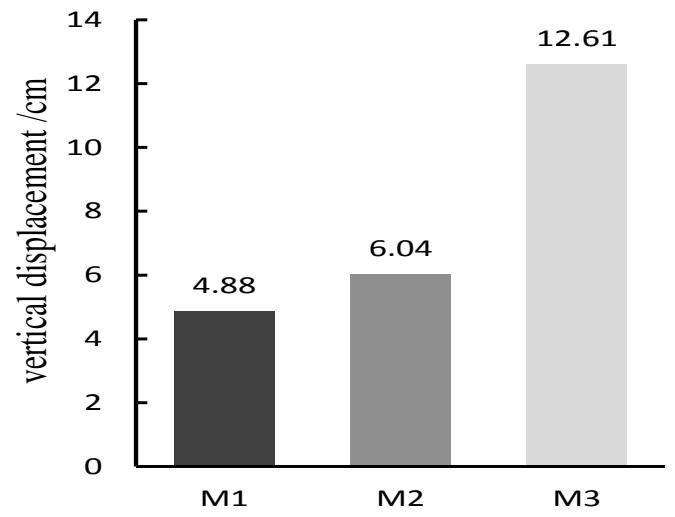

Figure 5. Comparison of vertical displacements of M1, M2 and M3.

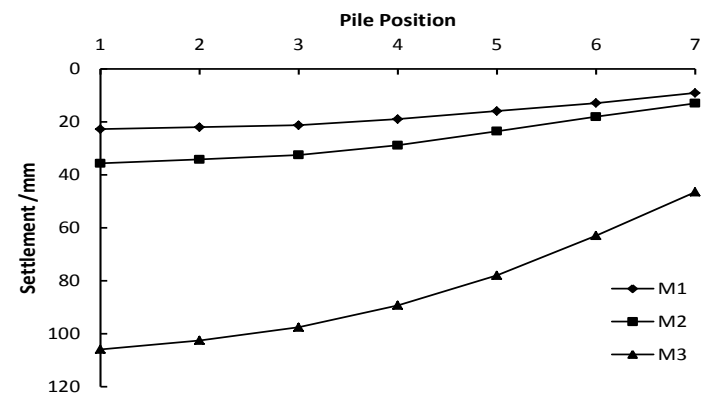

Figure 6. Curves of the pile cap settlement

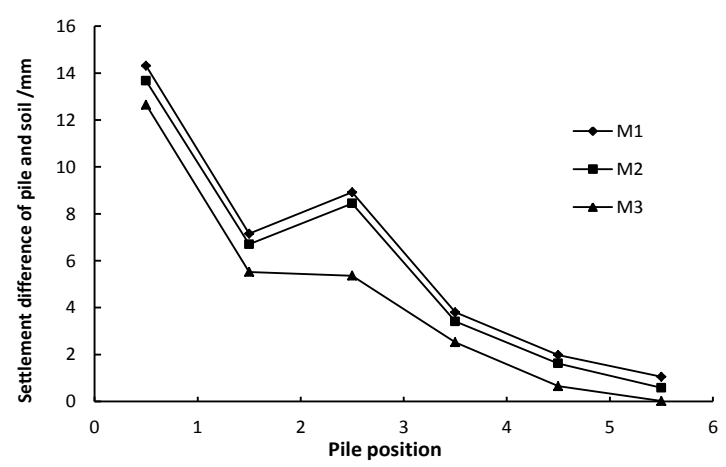

Figure 7. Curves of differential settlements of piles and soil. 
Fig. 8 shows the settlement of the pile tips with the three different bearing stratums. The settlement of the pile tips of M1 and M2 was only a little different and the pile tips do not punched into the bearing stratum. The settlement of M3 reached the maximum in the center of the embankments, while the settlement of M3 at the foot of embankments was obviously decreased at the same time, and the punching phenomenon of the pile tips occurred obviously, which showed that the change of the bearing stratum had a great influence on the settlement of the pile tips. The decrease of the strength of the bearing stratum caused gradually increase of the settlement of the piles.

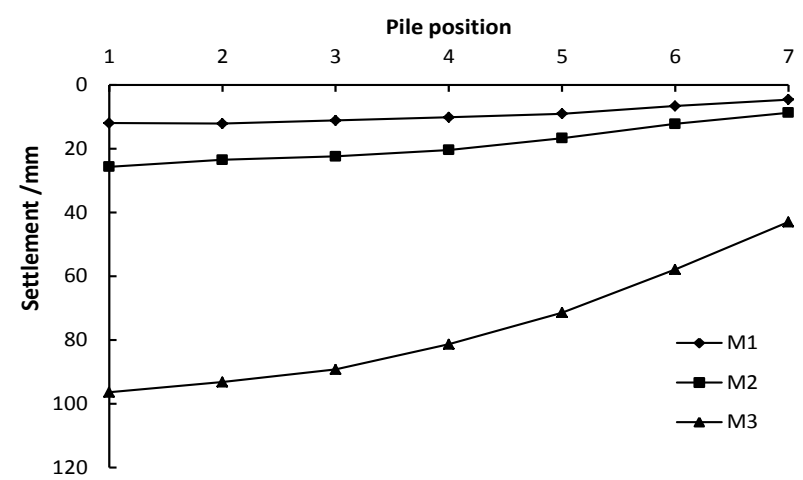

Figure 8. Curves of pile tips settlements.

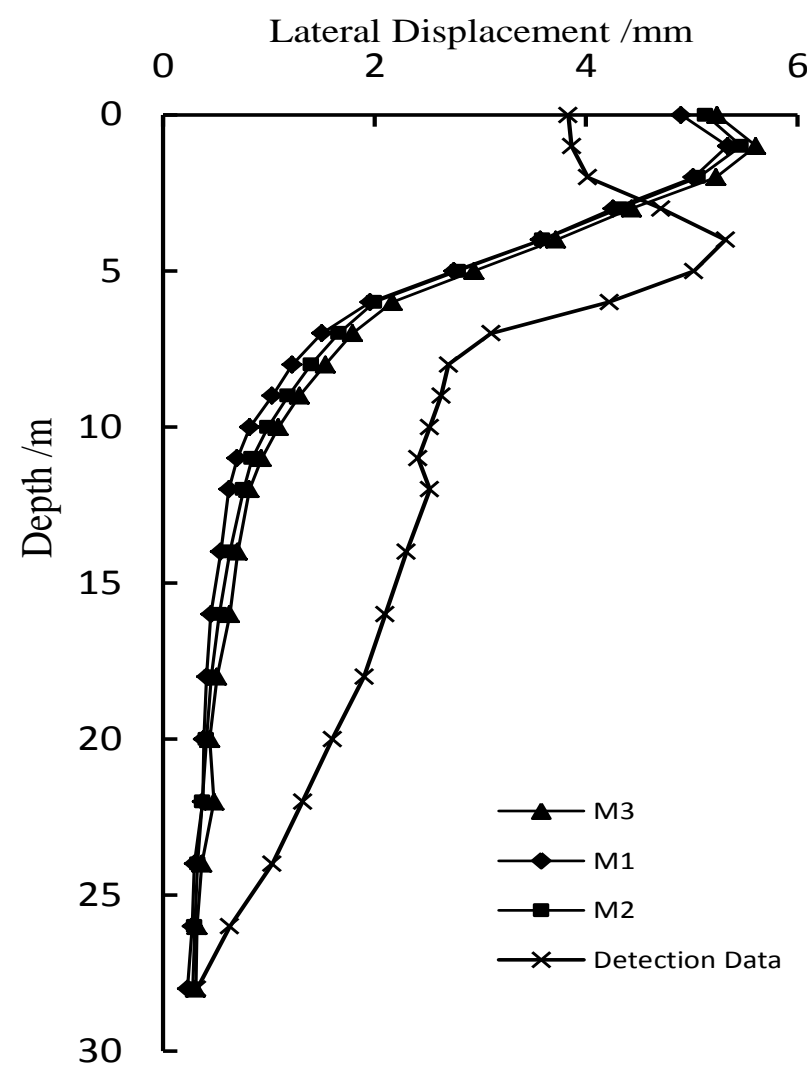

Figure 9. Curves of lateral displacements of the foundation.

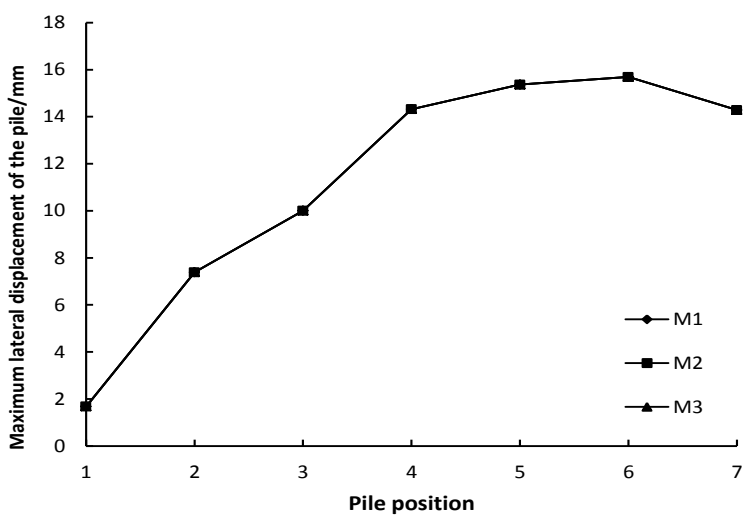

Figure 10. Curves of lateral displacements of the piles.

\section{Influence of Bearing Stratum on Lateral Displacement}

The mean values of the horizontal deformation at different depths of the foundation from the slope foot to the center of the embankment are shown in Fig. 9. The major lateral displacements occurred in the depth range of $8 \mathrm{~m}$ in the soft soil layer, and the maximum lateral displacement appeared in the depth of $5.5 \mathrm{~mm}$, which indicated the lateral displacements were less affected by the bearing stratum.

The lateral displacements of the piles are shown in Fig. 10. The lateral displacements of piles of the three models were basically the same, only $1.7 \mathrm{~mm}$ at the center of the embankment, and $14.3 \mathrm{~mm}$ at the foot of the embankment. Generally speaking, the lateral displacements were gradually increasing from center to both sides.

\section{CONCLUSION}

In this paper, the influence of bearing stratum on the deformation of reinforced and piled embankment was studied by using numerical analysis as the main method and comparison with field test results. The findings were concluded as follows:

(1) The mechanical behavior of the bearing stratum had a great influence on the failure mode of geosynthetic reinforced and piled embankment. It could be better to extend the pile length or increase the bearing capacity of the bearing stratum to ensure the foundation stability.

(2) The bearing stratum had a great influence on the settlement of the embankments, piles and foundations. When the strength of bearing stratum was reduced, the overall settlement increased.

\section{ACKNOWLEDGMENT}

Financial support for this work is gratefully acknowledged from the Natural Science Foundation of Guangxi Grant 2015GXNSFBA139236 and Guangxi University Scientific Research Project Grant KY2015ZD044. All the support is greatly appreciated.

\section{REFERENCES}

[1] Van Eekelen, S.J.M., Bezuijen, A., Lodder, H.J., Van Tol, A.F.. Model experiments on piled embankments. PartI. Geotextiles and Geomembranes, 2012a, 32: 69-81. 
[2] Le Hello, B., Villard, P.. Embankments reinforced by piles and geosynthetics - Numerical and experimental studies dealing with the transfer of load on the soil embankment. Engineering Geology, 2009, 106(1-2), 78-91.

[3] Van Eekelen S.J.M., Bezuijen A.F., Van Tol A.F.. Analysis and modification of the British Standard BS8006 for the design of piled embankments. Geotextiles and Geomembrane, 2011, 29(1): 345-359.
[4] Briançon, L.,Delmas, Ph., Villard, P.. Study of the load transfer mechanisms in reinforced pile supported embankments. In: Proceedings of 9ICG, Brazil, 2010, pp.1917-1920.

[5] Van Eekelen, S.J.M., Bezuijen, A., Lodder, H.J., Van Tol, A.F.. Model experiments on piled embankments. Part II. Geotextiles and Geomembranes, 2012b, 32: 82-94.

[6] Gebreselassie, B., Lüking, J., Kempfert, H.G.. Influence factors on the performance of geosynthetic reinforced and pile supported embankments. In: Proceedings of 9ICG, Brazil, 2010, pp. 1935-1940. 